\title{
BIOSORPTION OF COPPER(II) IONS USING TIMBER INDUSTRY WASTE BASED BIOMASS
}

\author{
S. Rani ${ }^{1,2,3}$, M. Bansal ${ }^{4}$, K. Kaur ${ }^{5}$ and S. Sharma ${ }^{5^{*}}$ \\ ${ }^{1}$ Department of YCoE, Punjabi University Guru Kashi Campus, \\ Talwandi Sabo-151302(Punjab) India. \\ ${ }^{2}$ Research Scholar, I.K.Gujral Punjab Technical University, Kapurthala-144603(Punjab) India. \\ ${ }^{3}$ Applied Chemistry and Polymer Science Laboratory, Department of Chemistry, Maharaja \\ Ranjit Singh Punjab Technical University, Bathinda-151001(Punjab) India. \\ ${ }^{4}$ Department of Civil Engineering, Giani Zail Singh Campus College of Engineering and \\ Technology, Bathinda-151001(Punjab) India. \\ ${ }^{5}$ Department of Chemistry, Maharaja Ranjit Singh Punjab Technical University, Bathinda- \\ 151001(Punjab) India. \\ *E-mail: harprit6920@gmail.com
}

\begin{abstract}
The processing and characterization of timber industry waste based saw dust and its biosorption studies towards $\mathrm{Cu}$ (II) ions is the focus of the present study. The processing of saw dust involved (i) boiling with water (ii) treatment with formaldehyde and (iii) treatment with sulphuric acid to get three new adsorbents abbreviated as SDB (boiled saw dust), SDF (formaldehyde treated saw dust) and SDS (sulphuric acid treated saw dust), respectively. CHNSO, SEM-EDS, FTIR and BET surface area techniques were used for the characterization of SDB, SDF and SDS. These adsorbents were used for the comparative investigation of $\mathrm{Cu}$ (II) ions remediation in a batch process. Effects of procedural variables like $\mathrm{pH}$, contact period, starting concentration of $\mathrm{Cu}$ (II) ions, the quantity of adsorbent, temperature and agitation speed were investigated for the removal of metal ions under study on SDB, SDF and SDS adsorbents. Isothermal studies were carried out using Langmuir, Freundlich, Dubinin-Radushkevich and Temkin isotherm models. From Langmuir isotherm, the maximum adsorption capacity was calculated as 98.81 , 178.57 and $142.85 \mathrm{mg} / \mathrm{g}$ for SDB, SDF and SDS adsorbents, respectively. Kinetic studies indicate that the rate of Cu (II) ions adsorption follows pseudo-second-order kinetics. Studies of free energy changes suggest the process of biosorption as spontaneous and feasible. Enthalpy change values indicate the process of adsorption to be exothermic for SDB, SDF and endothermic for SDS. The results of desorption studies revealed that biosorbents used in present work are promising biosorbents for remediating copper from aqueous solution.
\end{abstract}

Keywords: $\mathrm{Cu}$ (II) Biosorption, Low-cost Adsorbents, Kinetic, Isotherm Studies, Desorption.

(c) RASĀYAN. All rights reserved

\section{INTRODUCTION}

Contamination of water bodies, due to the discharge of metal ions containing untreated effluent by industries, poses a profound danger to the global environment. The major percentage of metal ions in water comprises of $\mathrm{Cd}, \mathrm{Ni}, \mathrm{Hg}, \mathrm{Cu}, \mathrm{Zn}, \mathrm{Pb}, \mathrm{Cr}$ and As. These metals are obnoxiously affecting the ecological community owing to their toxic behavior ${ }^{1}$. The presence of metal ions in water bodies often exceeds the permissible limit. Metals are non-biodegradable and get accumulated in the biotic community resulting in physiological and metabolic disorders ${ }^{2}$. They are generally persistent and are not degraded readily ${ }^{3}$. The driving force for the eviction of metal ion contaminants from the aquatic system is the health problems caused by their occurrence above permissible limit ${ }^{4}$. Several methodologies have been reported in the literature for addressing the contamination problem due to metal ions. These include membrane filtration, ion-exchange, reverse osmosis, photo-catalysis, electrocoagulation, precipitation, solvent extraction etc. Although, these physical and chemical treatment procedures are manageable, quick

Rasayan J. Chem., 12(3), 1247-1261(2019)

http://dx.doi.org/10.31788/RJC.2019.1235171

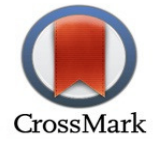


and effective for the expulsion of metal ions, simultaneously they carry the burden of high energy consumption, high cost and generation of auxiliary pollutants. To cover the above disadvantages, adsorption seems to be a sustainable and energy compatible method. But it has been found that conventional adsorbents such as activated charcoal are expensive and pose a threat to forests. To overcome the disadvantages related to the conventional adsorbents, biosorbents are being extensively used for metal ion removal in recent past and are proposing a promising sustainable alternative. The process of biosorption involves binding of solute molecules on the unoccupied active spaces present at the uppermost layer of the adsorbent. The solute molecules are held on to the surface of adsorbent by various physical and chemical interactions.

Copper (II) ions are frequently present in the industrial discharge. Copper is introduced into water bodies by the discharge of untreated water from various manufacturing, processing and refining industries ${ }^{5}$. The $\mathrm{Cu}$ (II) ions concentration approaches $100-120 \mathrm{mg} / \mathrm{L}$ in the effluent from the industries employing this metal in cleaning, plating and processing. This value is quite high as per water quality standards and needs to be reduced to permissible limit ${ }^{6} . \mathrm{Cu}$ is an essential element in human metabolism, plays an important part in the building of bones and development of the brain \& spinal cord. It is an integral part of certain important proteins and enzymes but becomes toxic at higher concentration ${ }^{7}$. Excessive intake of copper results in critical mucosal annoyance, extensive capillary injury, infuriation of central nervous system leading to a feeling of downheartedness, necrotic changes in liver and kidney ${ }^{8,9,10}$. Continuous inhalation of copper containing sprays results in an increased risk of lung cancer among the exposed workers. Neurotoxic nature of accumulation of copper in the nuclei of brain cells results in "Wilson's disease".

Considering the health hazards associated with intake of copper, research studies have been centered on ejecting of $\mathrm{Cu}$ metal ions from waste water employing various adsorbents. Metal ions uptake studies using several adsorbents including rice husk ${ }^{11}$, wheat straw ${ }^{12}$, Palm oil fruit shell ${ }^{13}$, coconut shell ${ }^{14}$, Pinus Sylvestris sawdust ${ }^{15}$, algal biomass ${ }^{16}$, lichen biomass ${ }^{6}$, chestnut shell ${ }^{8}$, poplar tree (Samson clone) sawdust ${ }^{17}$, phosphoric acid activated carbon of Bahuinia Purpurea leaves ${ }^{18}$ and rubber wood sawdust, sawdust of oak modified by treatment with $\mathrm{HCl}^{10}$, have been accomplished in the recent past. In the present work, sawdust has been opted for investigatory studies with the aim of getting a cost-efficient, biodegradable and abundantly available biosorbent which could be effectively employed for the scavenging of metal ions from industrial effluent at mega scale.

In the above context, the biosorption studies for the uptake of $\mathrm{Cu}$ (II) ions on the adsorbents obtained by processing of Indian rosewood sawdust have been carried out. Processing of sawdust involves boiling (SDB), treatment with formaldehyde (SDF) and treatment with sulphuric acid (SDS). Boiling sawdust removes tannin like water-soluble components, treatment with formaldehyde leads to polymerization of the color causing compounds ${ }^{19}$ and sulphuric acid treatment results into the expanded surface area of biosorbent. The three forms of adsorbents have been structurally elucidated employing SEM-EDS, FTIR, CHNSO and BET techniques. Pore volumes of the adsorbents have also been determined to find out the comparison between adsorption efficacy of the three adsorbents. Equilibrium isotherm, thermodynamic and kinetic explorations are performed using processed adsorbents to observe the mechanisms and nature of the biosorption process. Desorption studies have been done using different desorbing solutions.

\section{EXPERIMENTAL}

\section{Materials}

AR grade chemicals and reagents were used for the current study. Sodium hydroxide $(\mathrm{NaOH})$, sodium bicarbonate $\left(\mathrm{NaHCO}_{3}\right)$, sulphuric acid $\left(\mathrm{H}_{2} \mathrm{SO}_{4}\right)$, formaldehyde ( $\left.\mathrm{HCHO}\right)$, copper (II) sulphate pentahydrate $\left(\mathrm{CuSO}_{4} .5 \mathrm{H}_{2} \mathrm{O}\right)$ and hydrochloric acid $(\mathrm{HCl})$ were purchased from LOBA Chemie Pvt. Ltd, India. To prepare $\mathrm{Cu}$ (II) $(1000 \mathrm{mg} / \mathrm{L})$ stock solution, $\mathrm{CuSO}_{4} \cdot 5 \mathrm{H}_{2} \mathrm{O}$ was dissolved in demineralized water. The solutions of required concentrations were prepared by appropriate dilution of the above solution. The $\mathrm{pH}$ adjustment of the solutions was done with $\mathrm{HCl}$ or $\mathrm{NaOH}(0.1 \mathrm{M})$.

\section{Processing of Adsorbents}

Saw dust of Indian rosewood was obtained from a local saw mill of Bathinda, Punjab, India. The raw saw dust was processed to obtain three different biosorbents by the procedures as given below. 
RASĀYAN J. Chem.

Vol. 12 | No. 3 |1247 - 1261| July - September | 2019

\section{Procedure for Boiling Treatment of Saw Dust (SDB)}

The raw saw dust was dried under the sun and the identifiable unwanted materials were removed by hand picking. The material was ground in an electrical mixer grinder and sieved through a sieve of 300 micron size, followed by boiling with double distilled water for 8 hours to get rid of colored impurities and then filtered. The residual sawdust was washed several times till the filtrate becomes colorless and further it was hot air dried at $70^{\circ} \mathrm{C}$ for 24 hours.

\section{Treatment of Saw Dust with Formaldehyde (SDF)}

The powdered sawdust was kept in 1\% formaldehyde solution in the ratio 1:5 (saw dust : formaldehyde) at $25^{\circ} \mathrm{C}$ for 24 hours to immobilize the water-soluble colored impurities followed by filtration. The excessive formaldehyde was eluted with distilled water followed by the activation of residue at $70^{\circ} \mathrm{C}$ for 24 hours ${ }^{20}$. The prepared adsorbent was then sieved using 300 microns sieve.

\section{Preparation of Sulphuric Acid Treated Saw Dust (SDS)}

The sun-dried raw saw dust devoid of water-soluble impurities was treated with concentrated $\mathrm{H}_{2} \mathrm{SO}_{4}$ in the ratio 2:1 (liquid volume: solid weight). It was then carbonized under vigilant heating. To remove excess acid, the treated sawdust was soaked in double distilled water followed by washing with $2 \%$ $\mathrm{NaHCO}_{3}(\mathrm{w} / \mathrm{v})$ solution ${ }^{21}$. Finally, the adsorbent, so obtained, was heated in an oven at $70^{\circ} \mathrm{C}$ for 24 hours and sieved through 300 microns mesh.

\section{Characterization and Measurements}

The biosorbents were characterized using FTIR, SEM-EDS, CHNSO and BET surface area analyzers. Perkin Elmer Spectrum Two FTIR spectrometer (using KBr Pellet) of Maharaja Ranjit Singh Punjab Technical University, Bathinda, Punjab, was used for the analysis of changes in functional group vibrational frequencies and surface functional groups of biosorbents. To analyze the surface morphology and metal ion distribution on the biosorbents surface, the SEM images of suitable magnification and resolution were obtained with model JEOL-JSM-6510LV, Japan. The elemental constitution of biosorbents was analyzed using EDS spectroscopic techniques on INCAX-act, Model 51-ADD0076, Oxford Instruments. SEM-EDS were carried out at SAI lab, Thapar University, Patiala, Punjab. BET surface area measurements along with the determination of pore volumes were done on Quantachrome Instruments version 10.01 (Nova Station B) by $\mathrm{N}_{2}$ adsorption-desorption technique. Elemental composition of the adsorbents was determined using CHNS analyzer (Thermo Finnigan) at SAIF, Panjab University, Chandigarh. Atomic Absorption Spectrophotometer of Model GBC-932 plus (Guru Jambheshwar University, Hissar) was employed to determine the residual concentration of metal ions under study. $\mathrm{pH}$ meter (Model LT-49) was employed for measuring the $\mathrm{pH}$ of various solutions. Calibration of $\mathrm{pH}$ meter with standard buffers of $\mathrm{pH} 4.0,7.0$ and 9.2 was performed every time before use. Mechanical shaking of aqueous solutions was carried on Orbital Incubator shaker of make Remi Scientific.

\section{Batch Experiments for Adsorption of Cu (II) Ions}

Batch mode technique was adopted for biosorption of $\mathrm{Cu}$ (II) ions to investigate the influence of variation of $\mathrm{pH}$, adsorbent mass and temperature. For this, the required amount of adsorbent was agitated with 100 $\mathrm{ml}$ of $\mathrm{Cu}$ (II) ions solution of strength $50 \mathrm{mg} / \mathrm{L}$ in conical flasks. The initial $\mathrm{pH}$ was adjusted in the range 2 to 5.8 , adsorbent mass was maintained as 0.1 to $3.0 \mathrm{~g}$ for SDB, SDF and 0.1 to $2.0 \mathrm{~g}$ for SDS, keeping temperature in the span $298-333 \mathrm{~K}$. The effect of variation in metal ions initial concentration, contact time and agitation speed was determined at $\mathrm{pH} 5.8,0.1 \mathrm{~g}$ of adsorbent dosage and $298 \mathrm{~K}$. To evaluate the aforesaid effects, the initial concentration, period of contact and agitation speed were varied in the span 5 - $250 \mathrm{mg} / \mathrm{L}$ for SDB, SDF \& 25 - $250 \mathrm{mg} / \mathrm{L}$ in case of SDS, 30 - 240 minutes, 50-250 rpm, respectively. Adsorption isotherm studies were conducted by changing initial $\mathrm{Cu}$ (II) concentrations from 5 to $250 \mathrm{mg} / \mathrm{L}$ for SDB, SDF and from 25 to $250 \mathrm{mg} / \mathrm{L}$ in case of SDS keeping pH 5.8, quantity of adsorbent $0.1 \mathrm{~g}$ and temperature at $298 \mathrm{~K}$. Experiments of kinetic studies were carried out at concentration; pH: $50 \mathrm{mg} / \mathrm{L}$; 5.8 for $100 \mathrm{ml}$ of $\mathrm{Cu}$ (II) ions solution for contact time in the range $5-180$ 
min. The removal percentage of cupric ions and adsorption capacity (q) was determined using the equations given below:

$$
\begin{aligned}
& \text { \%age Removal }=100\left(\frac{\mathrm{C}_{\mathrm{o}}-\mathrm{C}_{\mathrm{e}}}{\mathrm{C}_{\mathrm{o}}}\right) \\
& \text { Adsorption capacity }(q)=\mathrm{V}\left(\frac{\mathrm{C}_{\mathrm{o}}-\mathrm{C}_{\mathrm{e}}}{\mathrm{m}}\right)
\end{aligned}
$$

Where $\mathrm{C}_{\mathrm{o}}(\mathrm{mg} / \mathrm{L})$ - initial concentration of adsorbate, $\mathrm{C}_{\mathrm{e}}(\mathrm{mg} / \mathrm{L})$ - equilibrium concentration of adsorbate, $\mathrm{q}(\mathrm{mg} / \mathrm{g})$ - quantity of metal ion up taken / unit mass of solid material, $\mathrm{m}(\mathrm{g})$ - adsorbent quantity, $\mathrm{V}(\mathrm{L})$ - volume of cupric ion solution.

\section{Desorption Studies}

Desorption of metal ions from the biosorbents was performed in a batch process. For this, $100 \mathrm{ml}$ of 50 $\mathrm{mg} / \mathrm{L} \mathrm{Cu}$ (II) ions concentration was agitated in orbital incubator shaker for 120 minutes at $200 \mathrm{rpm}$ with $0.1 \mathrm{~g}$ of each adsorbent in a conical flask. After 120 minutes, the metal loaded adsorbent was separated by filtration and treated with $100 \mathrm{ml}$ of each of $\mathrm{HCl}(0.2 \mathrm{~N} \& 0.1 \mathrm{~N}), \mathrm{H}_{2} \mathrm{SO}_{4}(0.1 \mathrm{~N}), \mathrm{HNO}_{3}(0.1 \mathrm{~N}), \mathrm{NaOH}$ $(0.1 \mathrm{~N})$ and $\mathrm{KI}(0.1 \mathrm{~N})$ as desorbing agents. The solutions were again kept for agitation for $2 \mathrm{hrs}$. After filtration, the residual cupric ion concentration in the filtrate was determined by AAS. Desorption efficiency (\%) of $\mathrm{Cu}$ (II) ions was assessed by the underwritten equation ${ }^{22}$ :

$$
\text { Desorption efficiency }(\%)=\frac{\mathrm{C}_{\mathrm{d}}}{\mathrm{C}_{\mathrm{a}}} \times 100
$$

Where $C_{a}(m g / L)$ - concentration of up taken metal ions, $C_{d}(m g / L)$ - strength of metal ions in the filtrate after desorption.

\section{Characterization of Adsorbents}

\section{RESULTS AND DISCUSSION}

Functional groups of the components of the adsorbent are accountable for adsorption of metals ions onto their surface. To confirm the modification of the sawdust, FTIR spectral studies were performed on the raw, boiled, formaldehyde treated and sulphuric acid treated sawdust. Fig.-1 provides a comparison of FTIR spectra of RSD (raw sawdust), SDB, SDF and SDS adsorbents while Fig.-2 is a comparison of spectra of three adsorbents loaded with $\mathrm{Cu}$ metal ions.

The major functional groups present in Raw Indian rosewood sawdust (RSD) and its three processed forms (SDB, SDF, SDS) include $>\mathrm{C}=\mathrm{O},-\mathrm{COOH},-\mathrm{OH},-\mathrm{NH}_{2}$ for which, the vibrational peaks are mentioned in Table-1.

The purpose of boiling treatment to the sawdust was to remove the color imparting impurities. The removal of these impurities by mere boiling indicates that these were attached to the structurally complex sawdust through weak forces, probably hydrogen bonding. This fact is further supported by the notable changes in the peaks of functional groups involved in hydrogen bonding as compared to RSD (Table-1). In addition to these changes, the zone of range $1500-1427 \mathrm{~cm}^{-1}$ showed remarkable changes in the shape and intensity of peaks (Fig.-1). FTIR of copper-loaded SDB exhibited considerable changes in -OH, $-\mathrm{NH},-\mathrm{C}-\mathrm{O}$ stretching modes and $-\mathrm{OH}$ out of plane bending mode, thus supporting the adsorption of $\mathrm{Cu}$ (II) ion on SDB.

It is expected that on formaldehyde treatment of sawdust, formaldehyde may possibly react with amine functional groups of raw adsorbent, which affects the vibrational frequency associated with the concerned auxochromic group. The above consideration is further confirmed from the shifting of the peaks at 3348 to $3354 \mathrm{~cm}^{-1}, 1243$ to $1261 \mathrm{~cm}^{-1}$ and 1053 to $1035 \mathrm{~cm}^{-1}$, which are due to $-\mathrm{OH}$, $-\mathrm{NH}$ stretching, coupled $-\mathrm{C}-\mathrm{O},-\mathrm{OH}$ and $-\mathrm{C}-\mathrm{N}$ stretching, respectively. The cupric metal ion uptake on formaldehyde treated sawdust is supported by substantial displacements of the normal modes of vibrations corresponding to coupled $-\mathrm{C}-\mathrm{O},-\mathrm{OH}$ (In plane bending) mode, $-\mathrm{C}-\mathrm{N}$ stretching mode (Table-1). The broad band for the stretching of $-\mathrm{OH}$ located at $3348 \mathrm{~cm}^{-1}$ for RSD was displaced to $3385.15 \mathrm{~cm}^{-1}$, medium intensity peak at $898 \mathrm{~cm}^{-1}$ for $-\mathrm{OH}$ (out of plane bending) relocated to $769 \mathrm{~cm}^{-1}$ and also signal at 1243 moves to $1216 \mathrm{~cm}^{-1}$ in case of sulphuric acid treated sawdust. These changes can be ascribed to $-\mathrm{OH}$ group acidification, which may have partially detached from the sawdust on heating as a part of the treatment. The spectral variations of the FTIR spectrum for $\mathrm{Cu}$ (II) ion loaded SDS indicate the potent interaction of $\mathrm{Cu}$ (II) ions 
RASĀYAN J. Chem.

Vol. 12 | No. 3 |1247 - 1261| July - September | 2019

with the processed adsorbent (Table-1). The shift of $18 \mathrm{~cm}^{-1}$ for $-\mathrm{OH}$ stretching vibrational frequency, in this case, indicated the stronger adsorption of the ions as compared to SDB and SDF.

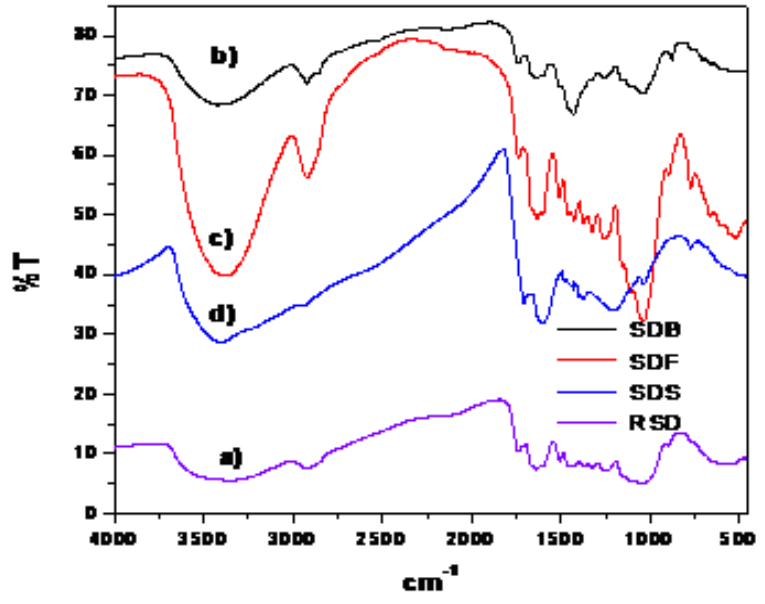

Fig.-1: FTIR of Adsorbents without $\mathrm{Cu}$

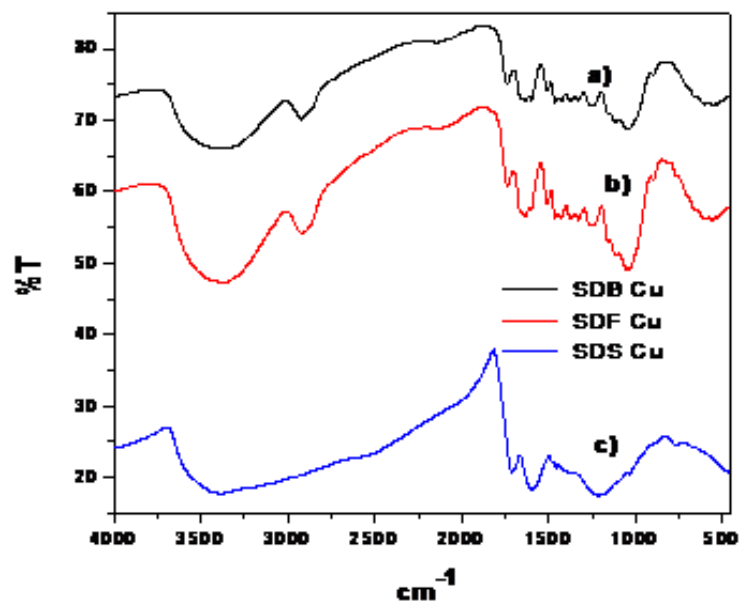

Fig.- 2: FTIR of Cu Loaded Adsorbents

Table-1: Pre and Post Adsorption FTIR Spectral Data of Adsorbents

\begin{tabular}{|c|c|c|c|c|c|c|c|}
\hline $\begin{array}{c}\text { Adsorbent } \\
\rightarrow \\
\text { Functional } \\
\text { Groups } \downarrow\end{array}$ & RSD & SDB & $\mathrm{SDB}-\mathrm{Cu}$ & SDF & $\mathrm{SDF}-\mathrm{Cu}$ & SDS & $\mathrm{SDS}-\mathrm{Cu}$ \\
\hline $\begin{array}{c}-\mathrm{OH} \\
-\mathrm{NH} \\
\text { stretching }\end{array}$ & $\begin{array}{l}3348 \\
(\mathrm{br}, \mathrm{s})\end{array}$ & $\begin{array}{c}3418 \\
\text { (br, s) }\end{array}$ & $\begin{array}{l}3351 \\
(\mathrm{br}, \mathrm{s})\end{array}$ & $\begin{array}{c}3354.28 \\
(\mathrm{br}, \mathrm{s})\end{array}$ & $\begin{array}{l}3356 \\
\text { (br, s) }\end{array}$ & $\begin{array}{c}3385.15 \\
(\mathrm{br}, \mathrm{s})\end{array}$ & $\begin{array}{c}3403 \\
\text { (br, s) }\end{array}$ \\
\hline $\begin{array}{c}-\mathrm{C}=\mathrm{O} \\
\text { stretching } \\
\text { (ketonic, } \\
\text { carboxylic } \\
\text { acid etc.) }\end{array}$ & $\begin{array}{c}1737-1602 \\
\text { (s) }\end{array}$ & $\begin{array}{c}1737-1600 \\
(\mathrm{~m})\end{array}$ & $\begin{array}{c}1737.75-1597 \\
(\mathrm{~m})\end{array}$ & $\begin{array}{c}1737.93-1601 \\
(\mathrm{~m})\end{array}$ & $\begin{array}{c}1736-1599 \\
(\mathrm{~m})\end{array}$ & $\begin{array}{c}1711-1570 \\
\text { (s) }\end{array}$ & $\begin{array}{c}1707-1603 \\
\text { (s) }\end{array}$ \\
\hline $\begin{array}{c}\text { Coupled } \\
-\mathrm{C}-\mathrm{O} \\
\text { stretching } \\
\text { and } \\
-\mathrm{O}-\mathrm{H} \text { in } \\
\text { plane } \\
\text { bending }\end{array}$ & $1243(\mathrm{~s})$ & $1261(\mathrm{~m})$ & $1250(\mathrm{~m})$ & $1261(\mathrm{~m})$ & $1253(\mathrm{~m})$ & $\begin{array}{c}1216(\mathrm{br}, \\
\mathrm{s})\end{array}$ & $\begin{array}{l}1214(\mathrm{br}, \\
\mathrm{s})\end{array}$ \\
\hline $\begin{array}{c}-\mathrm{C}-\mathrm{N} \\
\text { stretching }\end{array}$ & $1053(\mathrm{~s})$ & $1052(\mathrm{~s})$ & $1038(\mathrm{~s})$ & $1035.32(\mathrm{~s})$ & $1053(\mathrm{~s})$ & $1036(\mathrm{~s})$ & $1036(\mathrm{~s})$ \\
\hline $\begin{array}{l}-\mathrm{O}-\mathrm{H} \text { (out } \\
\text { of plane } \\
\text { bending) }\end{array}$ & $898(\mathrm{~m})$ & $878(\mathrm{~m})$ & $898(\mathrm{~m})$ & $896(\mathrm{~m})$ & $898(\mathrm{~m})$ & $769(\mathrm{~m})$ & $772(\mathrm{~m})$ \\
\hline
\end{tabular}

BET analyzer provided measurements for adsorbents' BET surface area and pore volume. It showed the BET surface area for SDB as $235.786\left(\mathrm{~m}^{2} / \mathrm{g}\right)$ and on treatment with formaldehyde and sulphuric acid, it increased to 285.385 and $514.996\left(\mathrm{~m}^{2} / \mathrm{g}\right)$ respectively. BJH pore volume of SDB, SDF and SDS were found as $0.180,0.214$ and $0.426\left(\mathrm{~cm}^{3} / \mathrm{g}\right)$ respectively. From Table-2 it is observed that SDS has the highest surface area among the three adsorbents and hence highest adsorption efficiency for the remediation of metal ions. This may be attributed to the availability of more number of active positions on adsorbent's surface. 
RASĀYAN J. Chem.

Vol. 12 | No. 3 |1247 - 1261| July - September | 2019

Table-2: Surface Area and Pore Volume measured Values of prepared Adsorbents

\begin{tabular}{c|c|c}
\hline Adsorbent & Surface area $\left(\mathrm{m}^{2} / \mathrm{g}\right)$ & Pore volume $\left(\mathrm{cm}^{3} / \mathrm{g}\right)$ \\
\hline SDB & 235.786 & 0.180 \\
\hline SDF & 285.385 & 0.214 \\
\hline SDS & 514.996 & 0.426 \\
\hline
\end{tabular}

The presence of various elements in the adsorbents was analyzed using CHNSO element analyzer. The elemental analysis of SDB gave a percentage of $\mathrm{C}, \mathrm{H}, \mathrm{O}$ and $\mathrm{N}$ as 44.489, 5.355, 32.808, 0.367, SDF gave $44.414,5.415,32.555,0.516$ and SDS gave a percentage of $\mathrm{C}, \mathrm{H}, \mathrm{O}$ as 52.384, 2.919, 21.518, respectively. The increased percentage of carbon and decreased percentage of hydrogen and oxygen in SDS indicates the partial carbonization of sawdust.

The morphological variations caused by the three different treatments given to raw sawdust, were revealed with the help of SEM images (Fig.-3 and 4). EDS images of biosorbents showed the existence of carbon and oxygen in the biomass before adsorption whereas after adsorption additional signal for $\mathrm{Cu}$ was obtained indicating the adsorption of copper (Fig.-5 and 6) by the adsorbents.

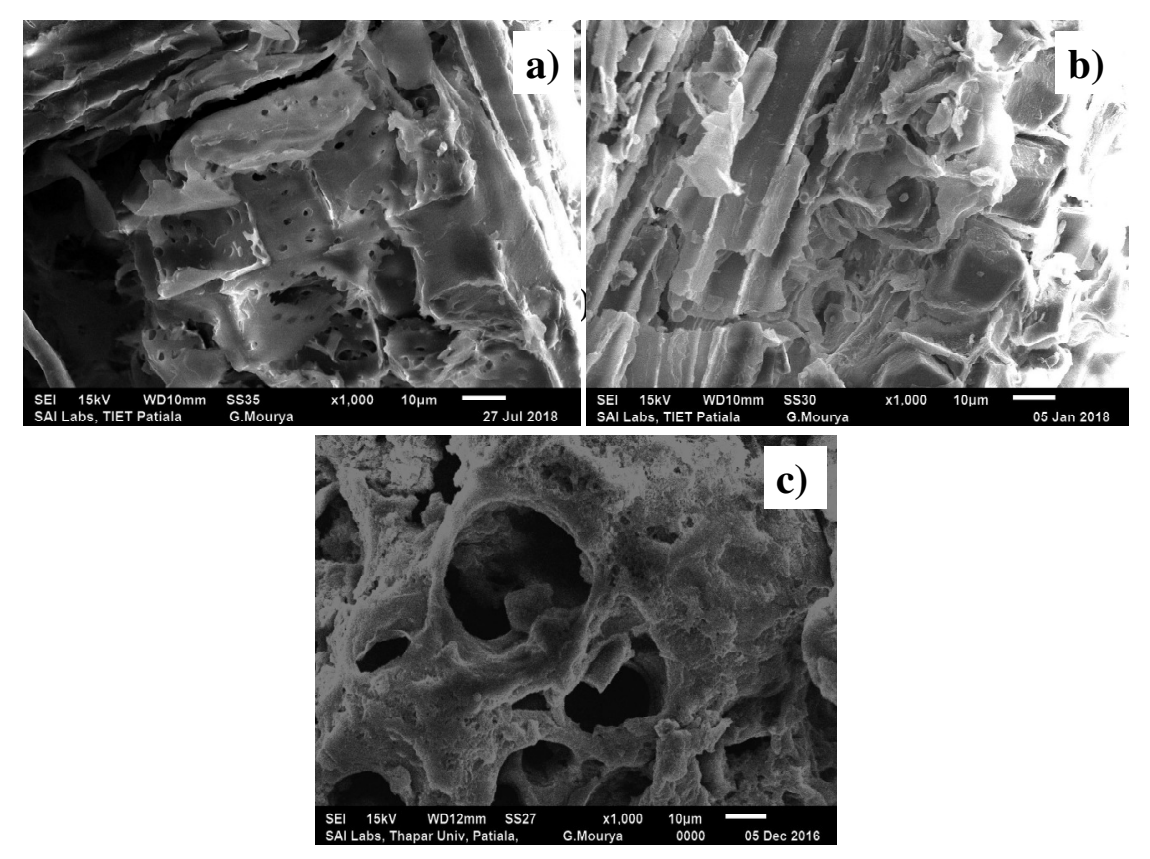

\section{Batch Experiments}

Fig.-3: SEM of Adsorbents before Adsorption (a) SDB ( b) SDF (c) SDS

\section{Influence of $\mathbf{p H}$}

Among the various significant parameters in the process of adsorption, $\mathrm{pH}$ of metal ion solution owes a considerable role. The $\mathrm{pH}$ of the reaction mixture is a decisive parameter for the surface charge of adsorbent and ionization of surfacial deprotonable functional groups of the adsorbent ${ }^{23}$. To study the influence of $\mathrm{pH}$ variation on the adsorption capacity of adsorbents under study, the $\mathrm{pH}$ was adjusted in the range 2.0 to 5.8 keeping the strength of $\mathrm{Cu}$ (II) ions as $50 \mathrm{mg} / \mathrm{L}$. The results showed that the percentage adsorption of cupric ions shows an increment as the $\mathrm{pH}$ is increased. The maximum adsorption capacity was noted at pH 5.8 (Fig.-7a) for all the three adsorbents. The percentage increase in adsorption for SDB, SDF and SDS was observed as $29.9-70.78,49.1-90.58$ and $34.3-91.55$, respectively. The low adsorption at $\mathrm{pH} 2$ is attributed to the blocking of characteristic surface functional units due to their protonation, thus they repel the metal ions. However, at elevated $\mathrm{pH}$, deprotonation of the functional groups takes place. Consequently, the surface of the biomass acquires a negative charge and attracts positively charged ions ${ }^{24}$, resulting in an increased percentage of adsorption of cupric ions. These studies could not be performed above $\mathrm{pH} 5.8$ due to the formation of insoluble hydroxides. 

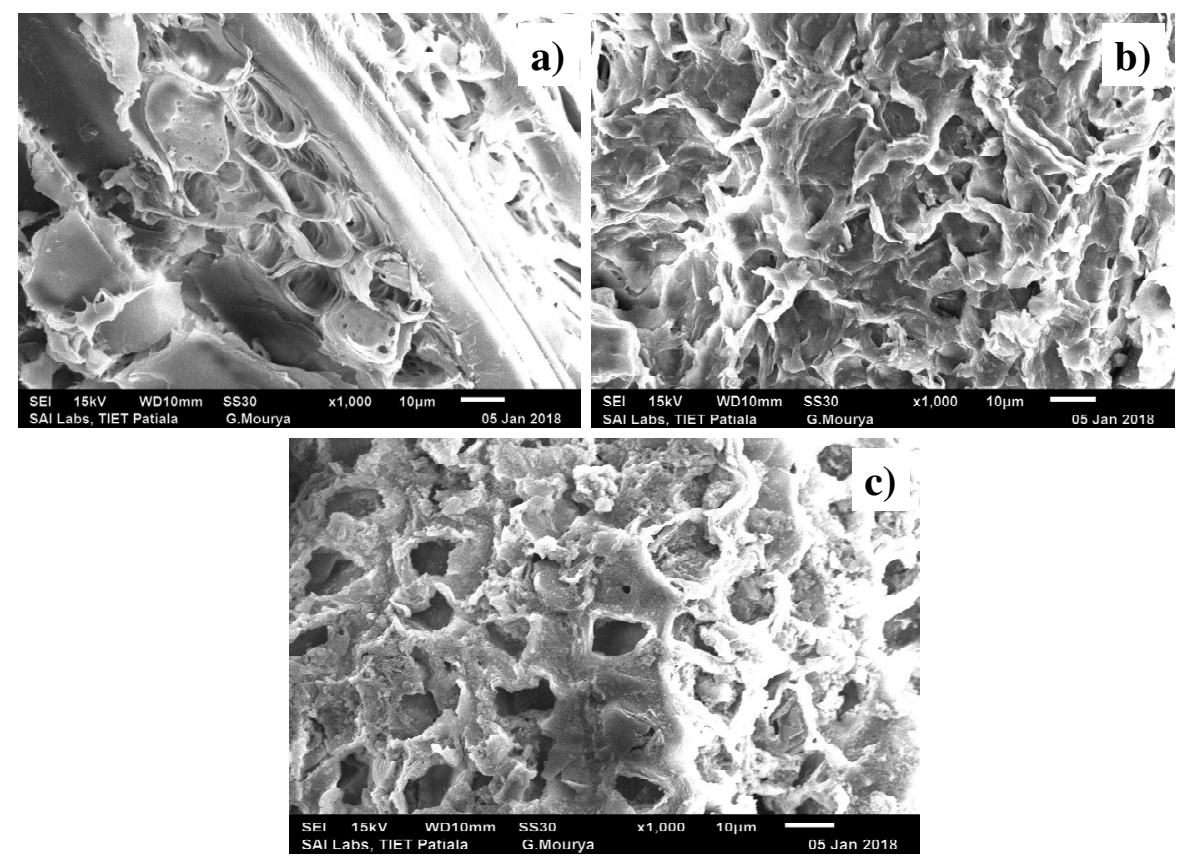

Fig.-4: SEM after Adsorption (a) Cu loaded SDB (b) Cu loaded SDF (c) Cu loaded SDS

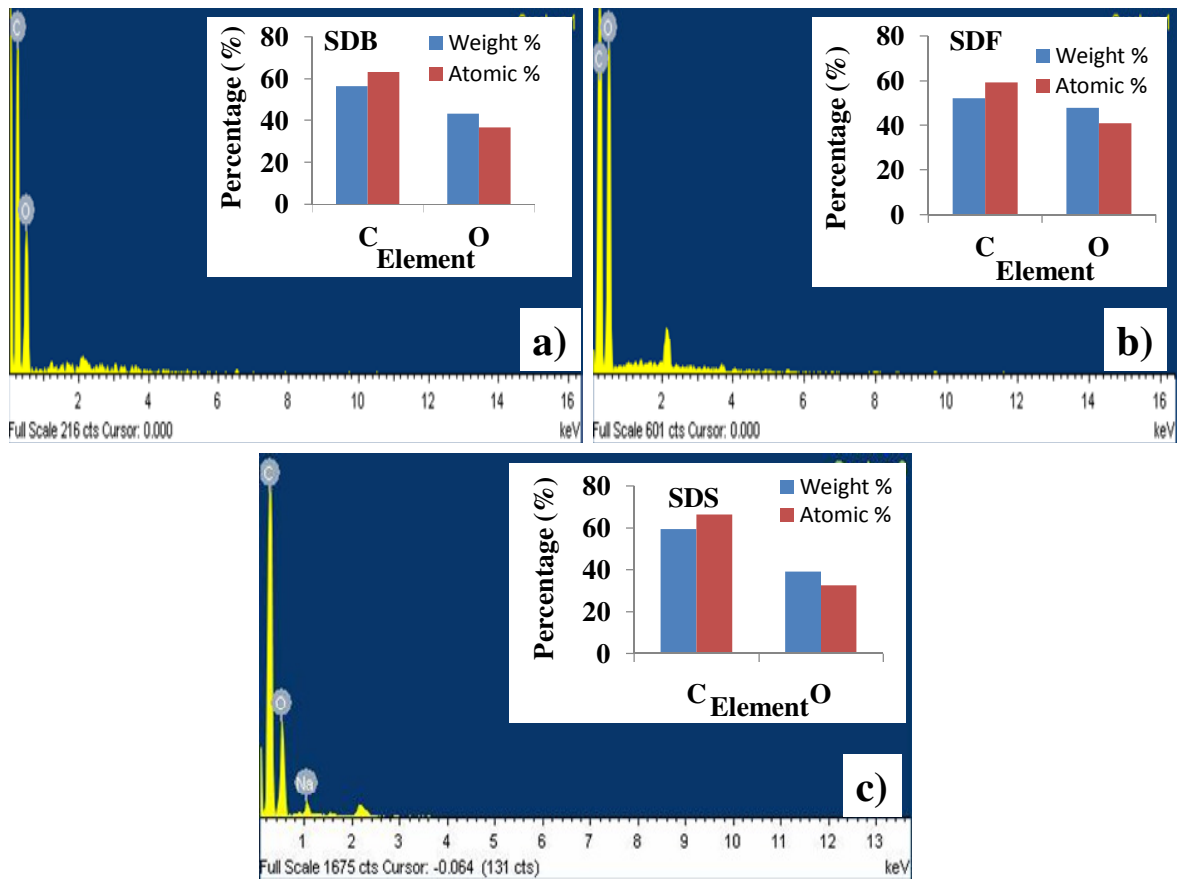

Fig.-5: EDS of Adsorbents before Adsorption (a) SDB ( b) SDF (c) SDS

\section{Effect of Dose of Adsorbent on the Removal of Divalent Copper}

The variation in adsorption efficiency of three adsorbents on increasing adsorbent dosage from $0.1-3.0 \mathrm{~g}$ for SDB, SDF and $0.1-2.0 \mathrm{~g}$ for SDS was investigated by taking $100 \mathrm{ml}$ solution of $\mathrm{Cu}$ (II) ions (50 $\mathrm{mg} / \mathrm{L})$ at $298 \mathrm{~K}$. It is inferred from Fig.-7b that increasing the dose of adsorbent, elevates the percentage removal of copper which is due to the availability of larger surface area for the process of adsorption to take place. For SDF and SDS, maximum removal was noted when the dosage of adsorbent is kept $0.1 \mathrm{~g}$, following gradual increment in adsorption and thereafter reaches a plateau indicating the attainment of equilibrium. Similar behavior was observed for SDB. 


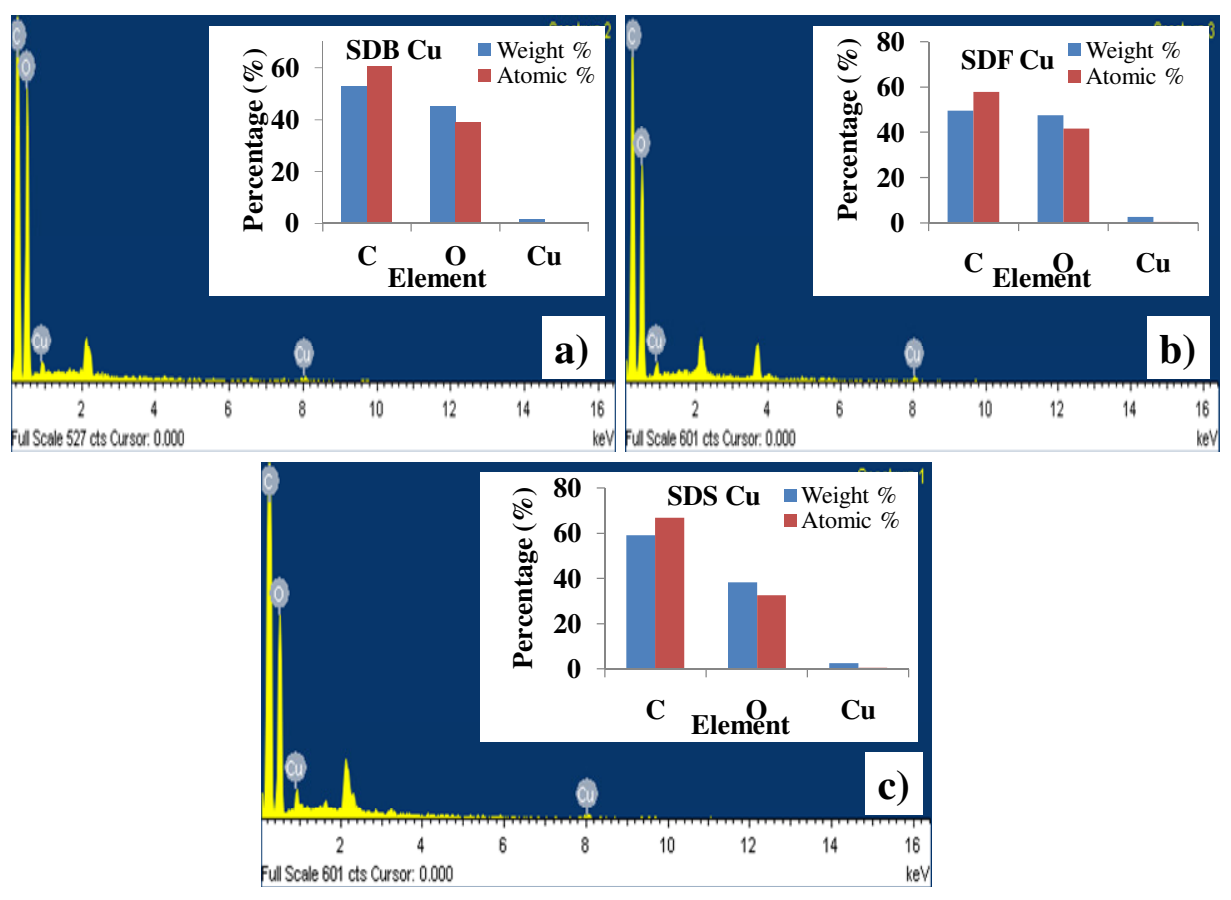

Fig.-6: EDS after Adsorption (a) Cu loaded SDB ( b) Cu loaded SDF (c) Cu loaded SDS

\section{Impact of Exposure Time on Copper (II) Metal Ions Removal}

The impacts of exposure period of adsorbent and metal ions upon biosorption of divalent copper was studied by taking $100 \mathrm{ml}$ solution of $\mathrm{Cu}$ (II) ions $(50 \mathrm{mg} / \mathrm{L})$ containing $0.1 \mathrm{~g}$ of adsorbent at $\mathrm{pH} 5.8$ and temperature $298 \mathrm{~K}$. The parameter was made to vary from 30 to 240 minutes in the interval of 30 minutes. The graphical representation of the results (Fig.-7c) depicts that the surface assimilation shows an increment in values as the contact time increases, attains maximum at 120 minutes and thereafter shows a decreasing trend. As per the above trends, it is deduced that a minimum of 120 minutes time is essential to attain the reaction equipoise. In the beginning, the assimilating material is available with abundant vacancies which lead to speedy assembling of metal ions from solution to on its surface, hence increasing trends were observed ${ }^{11}$. After 120 minutes, slow and almost constant percentage adsorption was seen because of filling up of active voids of adsorbent at equilibrium and also slower internal propagation of concerned impurities from the uppermost surface layer to the internal pores ${ }^{11,24}$.

\section{Initial Concentration Impacts}

To examine the influence of change in starting concentration of $\mathrm{Cu}$ (II) ions upon removal percentage using SDB, SDF and SDS adsorbents, the initial concentration was varied in the range $5-250 \mathrm{mg} / \mathrm{L}$ for SDB, SDF \& 25-250 mg/L for SDS, keeping other parameters constant (Fig.-7d). Increasing initial concentration of copper in the range $5-25 \mathrm{mg} / \mathrm{L}$ the $\%$ adsorption decreases for SDB and SDF. But, a further increase in the factor to the value $50 \mathrm{mg} / \mathrm{L}$, results in an abrupt increase in adsorption and afterward it decreases. The abrupt increase in the adsorption at concentration $50 \mathrm{mg} / \mathrm{L}$ may be assigned to the higher concentration of metal ions in the vicinity of biosorbent as compared to the lower concentration. In the case of SDS, percentage adsorption of $\mathrm{Cu}$ (II) ions decreases in the span from 25$250 \mathrm{mg} / \mathrm{L}$. This behavior is likely to happen because, at the low amount of metal, the fraction of active vacancies with respect to the gross amount of metal is high. so, entire metallic cations are able to assimilate easily on adsorbent active sites and percentage adsorption is high. On the other hand, at high initial concentration, the above-mentioned ratio is low, thus less unoccupied pores are available for physio or chemisorption, resulting in decreased adsorption at high concentrations.

\section{Effect of Temperature on Sorption of Target Metal Ion}

To explore metal ion adsorption abilities of SDB, SDF and SDS, the temperature is varied from 298-333 K. The outcomes obtained are presented in Fig.-7e. For SDS, the percentage increase in adsorption of $\mathrm{Cu}$ 
RASĀYAN J. Chem.

Vol. 12 | No. 3 |1247 - 1261| July - September | 2019

(II) ion takes place with rising temperature, inferring endogonic adsorption reaction ${ }^{25}$. At high temperature, the higher energy of metal ions helps to attain activation energy required for adsorption easily thus, increasing the propagation of impurity from solution to adsorbent ${ }^{19}$. In the case of SDF and $\mathrm{SDB}$, a decrease in percentage adsorption is observed by a rise in temperature, indicating the process to be exothermic.

\section{Impact of Agitation Speed on Adsorption Performance of Adsorbents}

The effect of change in shaking speed on adsorption efficacy towards $\mathrm{Cu}$ was probed by varying shaking speed from 50 to $250 \mathrm{rpm}$. Analysis of Fig.-7f depicts that adsorption efficiency increases by increasing shaking speed, reaches a maximum at $200 \mathrm{rpm}$ for all forms of processed sawdust and beyond $200 \mathrm{rpm}$, it decreased. When the solution is agitated, the movement of adsorbent particles is brisk and the rate of mass relocation of cations from solution to solid adsorbent is increased. Thus, the concentration of cations in the neighborhood of adsorbent's uppermost layer increases leading to increased diffusibility of cations. The decrease in adsorption above $200 \mathrm{rpm}$ is probably due to a decrease in diffusion of metal ions, as weak physical bonds probably got collapsed at high speed ${ }^{6,10}$.

\section{Adsorption Isotherm Studies}

The adsorption isotherm shows the equilibrium disposition of adsorbate molecules between the liquid and solid phase. These isotherms are important criteria to understand the type of association between adsorbate and adsorbent. These studies were performed with models involving two parameters like Langmuir, Freundlich, Dubinin-Radushkevich and Temkin.

\section{Langmuir Isotherm}

The Langmuir model presumes that the adsorbate molecules get adsorbed at particular homogeneous positions on the surface of adsorbent in the monomolecular layer. This model does not take into account any interaction between adsorbed molecules. The equation for this isotherm model is given as ${ }^{26}$ :

The linear form of equation is:

$$
\mathrm{q}_{\mathrm{e}}=\frac{\mathrm{q}_{\mathrm{m}} \mathrm{K}_{\mathrm{L}} \mathrm{C}_{\mathrm{e}}}{1+\mathrm{K}_{\mathrm{L}} \mathrm{C}_{\mathrm{e}}}
$$

$$
\frac{\mathrm{C}_{\mathrm{e}}}{\mathrm{q}_{\mathrm{e}}}=\frac{\mathrm{C}_{\mathrm{e}}}{\mathrm{q}_{\mathrm{m}}}+\frac{1}{\mathrm{q}_{\mathrm{m}} \mathrm{K}_{\mathrm{L}}}
$$

where, $C_{e}(\mathrm{mg} / \mathrm{L})$ - liquid-phase equilibrium concentration of metal ions, $\mathrm{q}_{\mathrm{e}}(\mathrm{mg} / \mathrm{g})$ - amount of adsorbate uptake at equilibrium, $\mathrm{q}_{\mathrm{m}}(\mathrm{mg} / \mathrm{g})$ - maximum monolayer adsorption capacity and $\mathrm{K}_{\mathrm{L}}(\mathrm{L} / \mathrm{mg})$ - Langmuir constant. $\mathrm{q}_{\mathrm{m}}$ and $\mathrm{K}_{\mathrm{L}}$ represent the adsorption efficiency and the energy of adsorption. These values are obtained from the plot of $\mathrm{C}_{\mathrm{e}} / \mathrm{q}_{\mathrm{e}}$ versus $\mathrm{C}_{\mathrm{e}}$ (Fig.-8a) and are given in Table-3. The key features of Langmuir isotherm can be revealed in terms of separation factor $\left(\mathrm{R}_{\mathrm{L}}\right)$ expressed as:

$$
\mathrm{R}_{\mathrm{L}}=\frac{1}{1+\mathrm{K}_{\mathrm{L}} \mathrm{C}_{\mathrm{o}}}
$$

Where, $C_{o}(\mathrm{mg} / \mathrm{L})$ - initial concentration of metal ions. The $\mathrm{R}_{\mathrm{L}}$ value signifies removal of adsorbate from liquid phase by adsorbent which can be either unfavourable $\left(R_{L}>1\right)$, linear $\left(R_{L}=1\right)$, favourable $\left(0<R_{L}\right.$ $<1)$ or irreversible $\left(\mathrm{R}_{\mathrm{L}}=0\right)^{8}$. These values for different initial amounts of $\mathrm{Cu}$ (II) ion for adsorption on $\mathrm{SDB}, \mathrm{SDF}$ and SDS came out in the range 0 to 1 indicating the process to be favorable.

\section{Freundlich Isotherm Model}

This is an empirical model which considers interactive forces between adsorbate molecules on the surface of adsorbent resulting in the formation of the multilayer. It also takes into account the non-uniform distribution of adsorption heat ${ }^{1}$.

Freundlich isotherm equation is as underwritten ${ }^{27}$ :

$$
\log \mathrm{q}_{e}=\log K_{\mathrm{f}}+\frac{1}{\mathrm{n}} \log \mathrm{C}_{e}
$$

Where, $\mathrm{q}_{\mathrm{e}}(\mathrm{mg} / \mathrm{g})$ - equilibrium concentration on the adsorbent, $\mathrm{C}_{\mathrm{e}}(\mathrm{mg} / \mathrm{L})$ - equilibrium concentration of adsorbate in solution, $\mathrm{K}_{\mathrm{f}}$ - constant related to adsorption capacity. $\mathrm{K}_{\mathrm{f}}$ and $1 / \mathrm{n}$ are Freundlich constants. For adsorption to be favorable ${ }^{28}$, $\mathrm{n}$ should be $1<\mathrm{n}<10 . \mathrm{K}_{\mathrm{f}}$ and $\mathrm{n}$ can be determined from a linear plot of $\log \mathrm{q}_{e}$ against $\log \mathrm{C}_{\mathrm{e}}$ (Fig.-8b). 

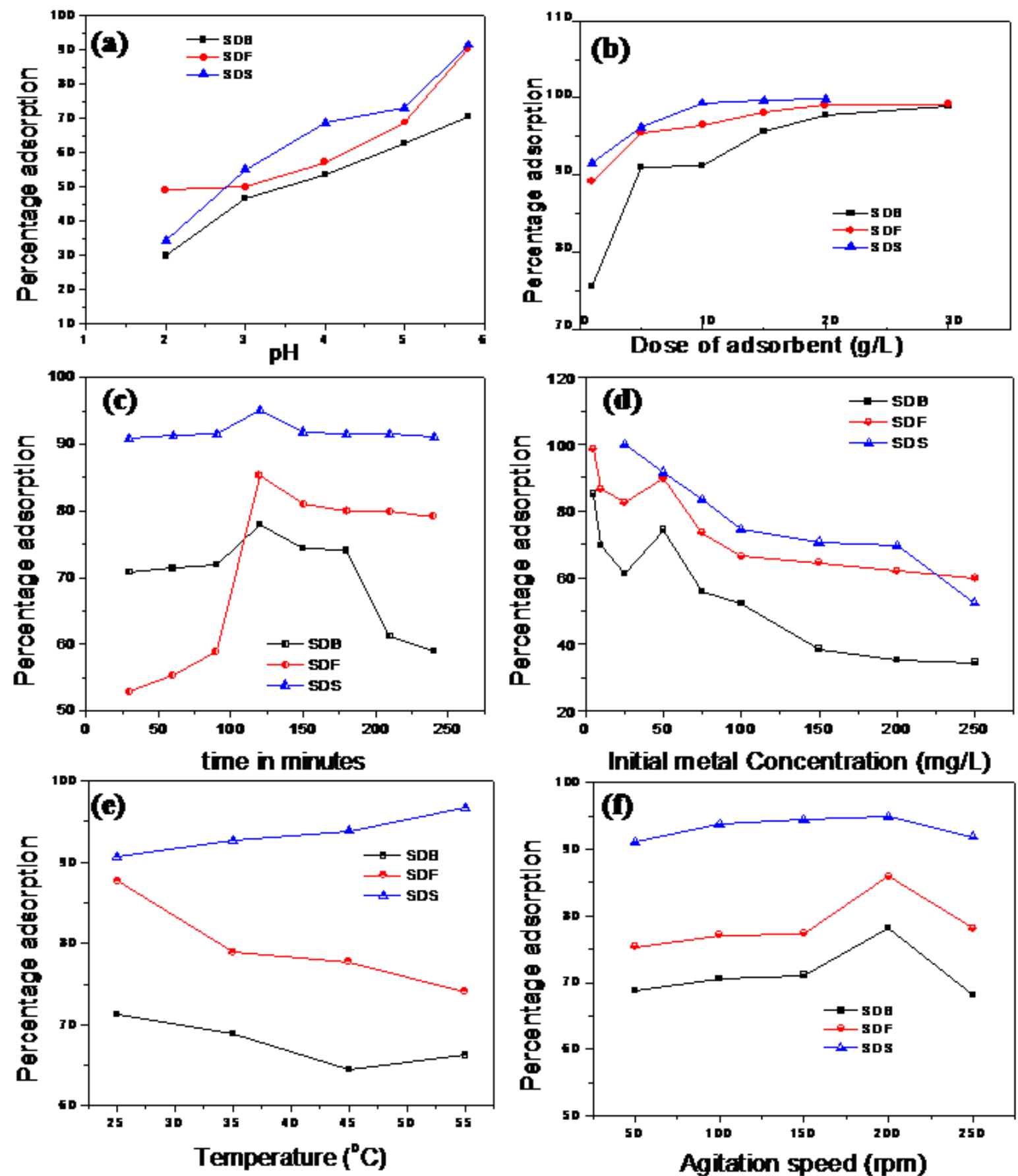

Fig.-7: Impact of Parameters on Adsorption of Cupric Ions (a) pH of Solution (b) Adsorbent Dose (c) Contact Time (d) Initial Concentration of Adsorbate (e) Temperature (f) Agitation Speed

\section{Dubinin-Radushkevich (D-R) Model}

$\mathrm{D}-\mathrm{R}$ isotherm model is described by the following exponential equation ${ }^{29}$ :

And its linear form is written as:

$$
q_{e}=q_{D} e^{-\lambda \varepsilon^{2}}
$$

$$
\ln q_{e}=\ln q_{D}-\lambda \varepsilon^{2}
$$

Where, $\mathrm{q}_{\mathrm{D}}(\mathrm{mg} / \mathrm{g})$ - maximum adsorption efficiency of adsorbent, $\mathrm{q}_{\mathrm{e}}(\mathrm{mg} / \mathrm{g})$ - mass of adsorbate adsorbed per unit mass of adsorbent, $\varepsilon$ - polanyi potential equal to RT $\ln \left(1+1 / \mathrm{C}_{\mathrm{e}}\right) . \lambda$ relates to mean free energy of adsorption per mole $(\mathrm{E})$ of adsorbent and $\mathrm{E}$ can be calculated by the following formula: 


$$
E=\frac{1}{\sqrt{2 \lambda}}
$$

Value of $E$ gives an idea of the nature of the adsorption process. Physical adsorption is indicated if the value of $\mathrm{E}$ is less than $8 \mathrm{kJmol}^{-1}$, the range $8-16 \mathrm{kJmol}^{-1}$ points toward ion-exchange adsorption whereas the range $20-40 \mathrm{kJmol}^{-1}$ refers to chemisorption. Values of $q_{D}$ and $\lambda$ (given in Table-3) are obtained from the graph between $\ln \mathrm{q}_{\mathrm{e}}$ and $\varepsilon^{2}$ (Fig.-8c).

\section{Temkin Isotherm Model}

The model contains a factor that absolutely considers adsorbent and adsorbate interactions. It presumes that there is a linear decrease in heat of adsorption of molecules in the layer with adsorption of adsorbate molecules owing to the interaction between adsorbent and adsorbate. Further, the process of adsorption involves even allocation of binding energies to the acquiring of maximum value ${ }^{30}$.

Temkin isotherm model can be described by the given equation ${ }^{31}$ :

$$
\begin{array}{r}
\mathrm{q}_{\mathrm{e}}=\frac{R T}{b} \ln \left(\mathrm{A}_{\mathrm{T}} \mathrm{C}_{\mathrm{e}}\right) \\
\text { or } \quad \mathrm{q}_{\mathrm{e}}=\frac{R T}{b} \ln \mathrm{A}_{\mathrm{T}}+\frac{R T}{b} \ln \mathrm{C}_{\mathrm{e}}
\end{array}
$$

Where, $A_{T}(L / g)$ - Temkin isotherm equilibrium binding constant indicating adsorbate-adsorbate interactions, $\mathrm{b}\left(\mathrm{Jmol}^{-1}\right)$ - Temkin isotherm constant, $\mathrm{R}\left(\mathrm{Jmol}^{-1} \mathrm{~K}^{-1}\right)$ - universal gas constant and $\mathrm{T}(\mathrm{K})$ temperature. The graph of $\mathrm{q}_{\mathrm{e}}$ against $\ln \mathrm{C}_{\mathrm{e}}$ (Fig.-8d) helps to determine $\frac{R T}{b}$ and $\mathrm{A}_{\mathrm{T}}$. From Table-3, the value of $\mathrm{A}_{\mathrm{T}}$ is found as highest for $\mathrm{Cu}$ (II) ions uptake using SDS biosorbent indicating largest adsorbateadsorbate interactions.
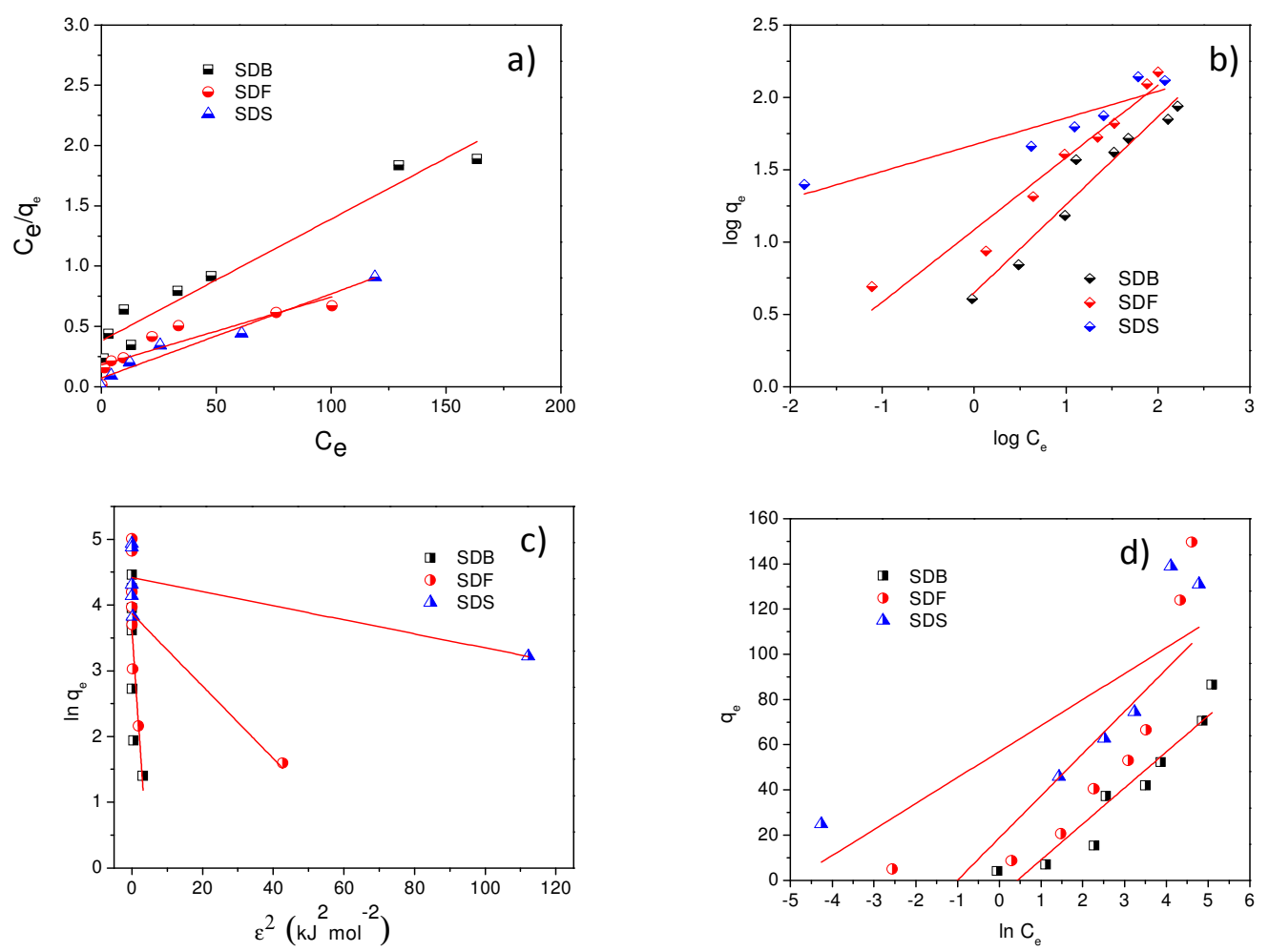

Fig.-8: Isotherms Models (a) Langmuir ( b) Freundlich (c) Dubinin-Radushkevich (d) Temkin

The calculated parameters including correlation coefficients $\left(\mathrm{R}^{2}\right)$ for all the isothermal studies are summarized in Table- 3. For SDB, $\mathrm{R}^{2}$ is in close agreement with investigational facts for Freundlich \& Langmuir isotherms, indicating the complex nature of adsorption in this particular case. For SDF, the $\mathrm{R}^{2}$ 
RASĀYAN J. Chem.

Vol. 12 | No. 3 |1247 - 1261| July - September | 2019

value indicates that the experimental data fit better into Freundlich isotherm pointing towards multilayer adsorption phenomenon on the heterogeneous surface. Whereas for SDS, $\mathrm{R}^{2}$ value suggests that the adsorption is uniform monolayer process corroborating Langmuir isotherm model.

Table-3: Isothermal Factors for Adsorption on SDB, SDF and SDS at $298 \mathrm{~K}$ towards Cupric Ions

\begin{tabular}{c|c|c|c|c|c|c|c|c|c|c|c|c|c}
\hline Adsorbent & \multicolumn{3}{|c|}{ Langmuir } & \multicolumn{2}{|c|}{ Freundlich } & \multicolumn{2}{c|}{ Dubinin-Radushkevich } & \multicolumn{3}{c}{ Temkin } \\
\hline & $\begin{array}{c}\mathrm{q}_{\mathrm{m}} \\
\mathrm{mg} / \mathrm{g})\end{array}$ & $\mathrm{K}_{\mathrm{L}}$ & $\mathrm{R}^{2}$ & $\begin{array}{c}\mathrm{R}_{\mathrm{L}} \\
(\mathrm{for} \\
50 \\
\mathrm{mg} / \mathrm{L})\end{array}$ & $\mathrm{K}_{\mathrm{f}}$ & $\mathrm{n}$ & $\mathrm{R}^{2}$ & $\begin{array}{c}q_{D} \\
(\mathrm{mg} / \mathrm{g})\end{array}$ & $\begin{array}{c}E \\
(\mathrm{~kJ} / \mathrm{mol})\end{array}$ & $\mathrm{R}^{2}$ & $\mathrm{~b}$ & $\mathrm{~A}_{\mathrm{T}}$ & $\mathrm{R}^{2}$ \\
\hline SDB & 98.81 & 0.0266 & 0.948 & 0.429 & 4.45 & 1.642 & 0.936 & 37.41 & 0.806 & 0.507 & 155.62 & 0.648 & 0.894 \\
\hline SDF & 178.57 & 0.0314 & 0.802 & 0.389 & 12.133 & 2.004 & 0.943 & 47.79 & 3.02 & 0.369 & 132.66 & 2.724 & 0.648 \\
\hline SDS & 142.85 & 0.0986 & 0.955 & 0.168 & 47.09 & 5.405 & 0.833 & 82.84 & 6.84 & 0.459 & 215.4 & 141.48 & 0.583 \\
\hline
\end{tabular}

Kinetics of Cu (II) Biosorption

Kinetic studies help in designing the sorption process and also provide the time required to reach equilibrium between the two phases involved in adsorption. Adsorption kinetic parameters were subjected to Pseudo-first order ${ }^{32}$, pseudo-second-order ${ }^{33}$, Intraparticle diffusion ${ }^{34}$ and Elovich models ${ }^{35}$ and are expressed by equations $13,14,15$ and 16 , respectively:

$$
\begin{aligned}
& \log \left(\mathrm{q}_{\mathrm{e}}-\mathrm{q}_{\mathrm{t}}\right)=\log \mathrm{q}_{\mathrm{e}}-\frac{k_{1}}{2.303} \mathrm{t} \\
& \frac{\mathrm{t}}{\mathrm{q}_{\mathrm{t}}}=\frac{1}{\mathrm{k}_{2} \mathrm{q}_{\mathrm{e}}^{2}}+\frac{1}{\mathrm{q}_{\mathrm{e}}} \mathrm{t} \\
& \mathrm{q}=\mathrm{k}_{\mathrm{i}} \mathrm{t}^{1 / 2}+\mathrm{C} \\
& \mathrm{q}_{\mathrm{t}}=\frac{1}{\beta} \ln (\alpha \beta)+\frac{1}{\beta} \ln \mathrm{t}
\end{aligned}
$$

Where $\mathrm{q}_{\mathrm{t}}\left(\mathrm{mg} \mathrm{g}^{-1}\right)$ - amount of $\mathrm{Cu}$ (II) adsorbed at time $\mathrm{t}$ (minutes), $\mathrm{q}_{\mathrm{e}}\left(\mathrm{mg} \mathrm{g}^{-1}\right)$ - amount of $\mathrm{Cu}$ (II) adsorbed at equilibrium, $\mathrm{k}_{1}\left(\mathrm{~min}^{-1}\right)$ and $\mathrm{k}_{2}\left(\mathrm{~g} \mathrm{mg}^{-1} \mathrm{~min}^{-1}\right)$ - rate constants, $\mathrm{q}\left(\mathrm{mg} \mathrm{g}^{-1}\right)$ - quantity of adsorbate adsorbed at time $\mathrm{t}, \mathrm{C}\left(\mathrm{mg} \mathrm{g}^{-1}\right)$ - constant, $\mathrm{k}_{\mathrm{i}}\left(\mathrm{mg} \mathrm{g}^{-1} \min ^{-1 / 2}\right)$ - intraparticle diffusion rate constant, $\alpha\left(\mathrm{mg} \mathrm{g}^{-1} \mathrm{~min}^{-1}\right)$ - initial sorption rate, $\beta\left(\mathrm{g} \mathrm{mg}^{-1}\right)$ - constant depending upon surface occupancy and activation energy for chemical adsorption. The values of $\mathrm{k}_{1}$ and $\mathrm{q}_{\mathrm{e}}$ in pseudo-first order model are obtained from the plot of $\log \left(\mathrm{q}_{\mathrm{e}}-\mathrm{q}_{\mathrm{t}}\right)$ versus $\mathrm{t}$ (Fig.-9a). Similarly, the graph of $\mathrm{t} / \mathrm{q}_{\mathrm{t}}$ and $\mathrm{t}$ (Fig.-9b) for pseudo-second order, gives $\mathrm{k}_{2}$ and $\mathrm{q}_{\mathrm{e}}$. The values of $\mathrm{k}_{\mathrm{i}}, \mathrm{C}$ in intraparticle diffusion model and the values of $\alpha, \beta$ in Elovich model are computed from the plot of $\mathrm{q}$ versus $\mathrm{t}^{1 / 2}$ and $\mathrm{q}_{\mathrm{t}}$ versus $\ln \mathrm{t}$, respectively (Fig.$9 \mathrm{c}, 9 \mathrm{~d})$. Table-4 proffers the calculated parameters of kinetic models.

Table-4: Calculated Kinetic Study Parameters

\begin{tabular}{c|c|c|c|c|c|c|c|c|c|c|c|c}
\hline Adsorbent & \multicolumn{3}{|c|}{ Pseudo-First Order } & \multicolumn{2}{c|}{ Pseudo-Second Order } & \multicolumn{2}{c|}{ Intraparticle Diffusion } & \multicolumn{3}{c}{ Elovich Model } \\
\hline & $\mathrm{k}_{1}$ & $\mathrm{q}_{\mathrm{e}} \mathrm{cal}$ & $\mathrm{R}^{2}$ & $\mathrm{k}_{2}$ & $\mathrm{q}_{\mathrm{e}} \mathrm{cal}$ & $\mathrm{R}^{2}$ & $\mathrm{k}_{\mathrm{i}}$ & $\mathrm{C}$ & $\mathrm{R}^{2}$ & $\alpha$ & $\beta$ & $\mathrm{R}^{2}$ \\
\hline SDB & $6.9 \times 10^{-3}$ & 4.109 & 0.718 & 0.025 & 38.02 & 0.999 & 0.321 & 34.008 & 0.764 & $1.63 \times 10^{13}$ & 0.935 & 0.784 \\
\hline SDF & $1.39 \times 10^{-2}$ & 0.149 & 0.942 & $1.37 \times 10^{-3}$ & 44.44 & 0.977 & 2.108 & 14.303 & 0.906 & 15.2 & 0.15 & 0.82 \\
\hline SDS & $3.68 \times 10^{-3}$ & 2.971 & 0.484 & 0.079 & 46.29 & 0.999 & 0.221 & 43.75 & 0.513 & $4.23 \times 10^{22}$ & 1.23 & 0.674 \\
\hline Units $\rightarrow$ & $\mathrm{min}^{-1}$ & $\mathrm{mg} / \mathrm{g}$ & - & $\begin{array}{c}\mathrm{gmg}^{-1} \\
\mathrm{~min}^{-1}\end{array}$ & $\mathrm{mg} / \mathrm{g}$ & & $\begin{array}{l}\mathrm{mg} \mathrm{g}^{-1} \\
\mathrm{~min}^{-1 / 2}\end{array}$ & $\mathrm{mg} \mathrm{g}^{-1}$ & - & $\begin{array}{c}\mathrm{mg} \mathrm{g}^{-1} \\
\mathrm{~min}^{-1}\end{array}$ & $\mathrm{~g} \mathrm{mg}^{-1}$ & - \\
\hline
\end{tabular}

Metallic ion adsorption is in compliance with pseudo-second-order kinetics as per the results obtained. Involvement of both adsorbent and adsorbate in adsorption is indicated by the experimental results. Similar results are also reported for adsorption of metallic ion on activated carbon prepared from Bahuinia Purpurea leaves ${ }^{18}$.

\section{Thermodynamic Studies}

The temperature of $298 \mathrm{~K}$ was maintained for doing thermodynamic experiments. The values of $\Delta \mathrm{G}^{\circ}, \Delta \mathrm{S}^{\circ}$ and $\Delta \mathrm{H}^{\circ}$ decide the spontaneity and nature of adsorption process. The values are obtained from the underwritten equations $^{36}$ :

$$
\Delta G^{\circ}=-R T \ln K_{d}
$$




$$
\begin{aligned}
& \Delta G^{\circ}=\Delta H^{\circ}-\mathrm{T} \Delta S^{\circ} \\
& K_{d}=\frac{C_{a}}{C_{e}} \\
& \ln K_{d}=-\frac{\Delta H^{\circ}}{R T}+\frac{\Delta S^{\circ}}{R}
\end{aligned}
$$

Where, $\mathrm{R}\left(8.314 \mathrm{Jmol}^{-1} \mathrm{~K}^{-1}\right)$ - gas constant, $\mathrm{K}_{\mathrm{d}}$ - equilibrium constant, $\mathrm{T}(\mathrm{K})$ - temperature, $\mathrm{C}_{\mathrm{a}}(\mathrm{mg} / \mathrm{L})$ concentration of cupric ions on adsorbent's surface and $C_{e}(\mathrm{mg} / \mathrm{L})$ - equilibrium concentration of cupric ions.

The values of $\Delta \mathrm{G}^{\circ}, \Delta \mathrm{S}^{\circ}$ and $\Delta \mathrm{H}^{\circ}$ (Table-5) were obtained from the plot of $\ln \mathrm{K}_{\mathrm{d}}$ and $1 / \mathrm{T}$. The feasibility and spontaneity of the adsorption process were indicated by $\Delta \mathrm{G}^{\circ}$ (-ve) value for all the adsorbents under consideration. A positive value of $\Delta \mathrm{H}^{\circ}$ for SDS and its negative value for SDB \& SDF showed endogonic $\&$ exogonic nature of adsorption respectively. Increase in randomness for SDS while its decrease for SDB \& SDF is indicated by $\Delta \mathrm{S}^{\circ}$ values. Results obtained for SDB and SDF are in similarity with the results observed for adsorption of $\mathrm{Cu}$ (II) on chestnut shell ${ }^{8}$, while for SDS, results show a similar trend as in case of modified oak sawdust ${ }^{10}$ and Hevea brasiliensis sawdust (modified and unmodified) ${ }^{36}$.
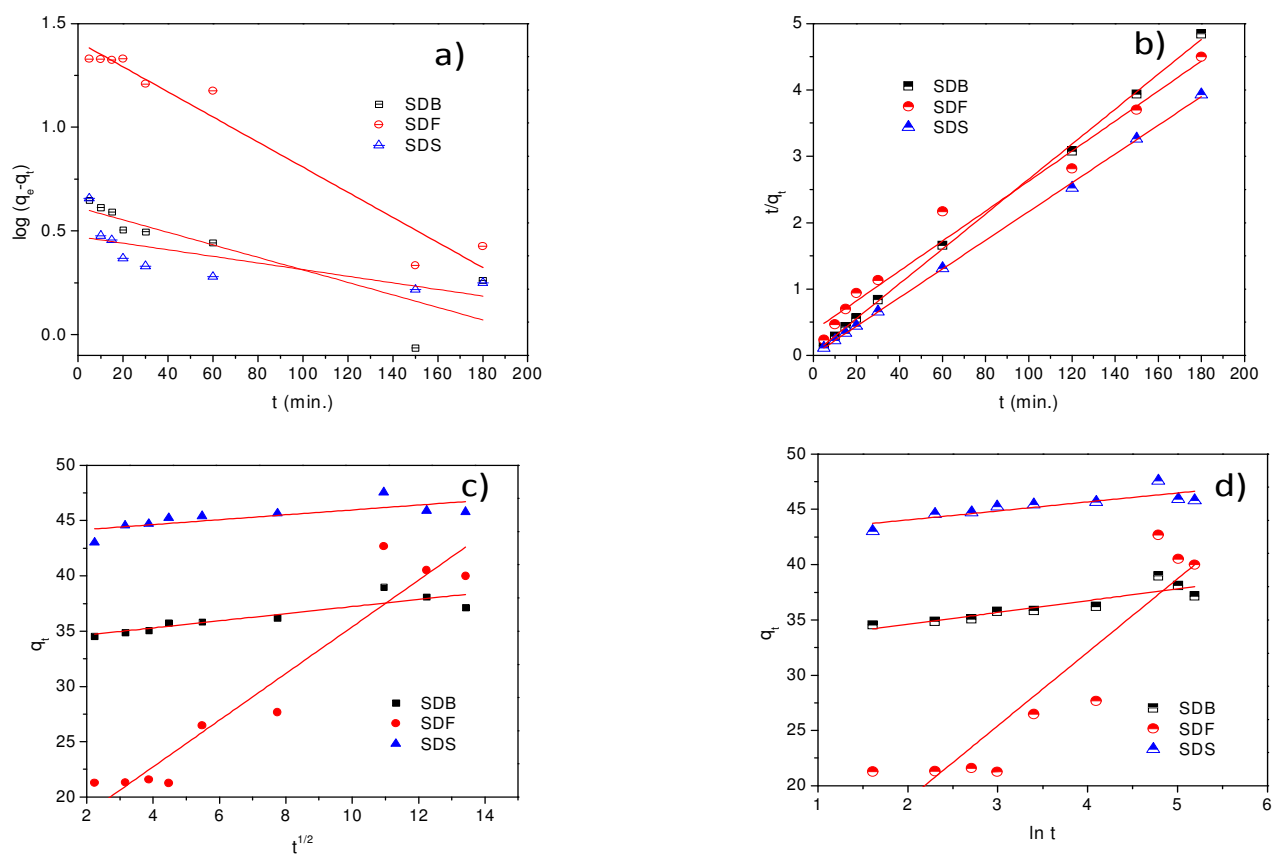

Fig.-9: Kinetic Studies (a) Pseudo-First Order (b) Pseudo-Second Order (c) Intraparticle Diffusion (d) Elovich Model

Table-5: Calculated Thermodynamic Parameters

\begin{tabular}{c|c|c|c}
\hline Adsorbent & $\Delta \mathrm{G}^{\circ}$ at $298 \mathrm{~K}$ & $\Delta \mathrm{H}^{\circ}$ & $\Delta \mathrm{S}^{\circ}$ \\
\hline $\mathrm{SDB}$ & -2.187 & -7.2 & -16.82 \\
\hline $\mathrm{SDF}$ & -4.56 & -22.824 & -61.274 \\
\hline SDS & -5.38 & 28.525 & 113.78 \\
\hline Units $\rightarrow$ & $\mathrm{kJ} \mathrm{mol}^{-1}$ & $\mathrm{~kJ} \mathrm{~mol}^{-1}$ & $\mathrm{~J} \mathrm{~mol}^{-1} \mathrm{~K}^{-1}$ \\
\hline
\end{tabular}

\section{Desorption Study}

Desorption studies of metal loaded adsorbents were performed using different desorbing agents. $\mathrm{HCl}$, $\mathrm{HNO}_{3}$ and $\mathrm{H}_{2} \mathrm{SO}_{4}$ showed maximum desorption efficiency in comparison to $\mathrm{NaOH}$ and $\mathrm{KI}$ solutions (Table-6). This is because, $\mathrm{H}^{+}$ions from acid compete with metal ions for binding sites of adsorbents. So, $\mathrm{Cu}$ (II) ions could be exchanged by $\mathrm{H}^{+}$ions. 
RASĀYAN J. Chem.

Vol. 12 | No. 3 |1247 - 1261| July - September | 2019

Table-6: Desorption Studies of Adsorbents using Different Desorbing Agents

\begin{tabular}{c|c|c|c|c|c|c}
\hline & \multicolumn{5}{|c}{ Desorbing agent } \\
\hline $\begin{array}{c}\text { Desorption efficiency (\%) } \\
\text { of Cu loaded adsorbents }\end{array}$ & $\mathrm{HCl}$ & $\mathrm{HCl}$ & $\mathrm{HNO}_{3}$ & $\mathrm{H}_{2} \mathrm{SO}_{4}$ & $\mathrm{NaOH}$ & $\mathrm{KI}$ \\
\hline SDB & 69.91 & 48.37 & 47.47 & 41.68 & 21.74 & 16.65 \\
\hline SDF & 63.82 & 44.22 & 41.16 & 38.25 & 14.7 & 8.34 \\
\hline SDS & 84.78 & 72.4 & 61.7 & 47.61 & 12.69 & 8.53 \\
\hline $\begin{array}{c}\text { Concentration of desorbing } \\
\text { agents } \rightarrow\end{array}$ & $0.2 \mathrm{~N}$ & $0.1 \mathrm{~N}$ & $0.1 \mathrm{~N}$ & $0.1 \mathrm{~N}$ & $0.1 \mathrm{~N}$ & $0.1 \mathrm{~N}$ \\
\hline
\end{tabular}

\section{CONCLUSION}

In present work, processing of sawdust of Indian rosewood was carried out to get three adsorbents namely SDB, SDF and SDS. The adsorbents were employed to evict aqueous cupric ions in batch mode. Effect of variation of different parameters indicates that the adsorbent SDS has highest percentage adsorption in comparison to SDB and SDF due to its higher surface area as indicated by BET surface area results. Freundlich and Langmuir's isotherms best fit the experimental data for SDB while for SDF, the Freundlich model is followed. In the case of adsorption by SDS, the Langmuir model explains uniform monolayer adsorption. Maximal adsorption efficacy is found as $98.81,178.57$ and $142.85(\mathrm{mg} / \mathrm{g})$ for SDB, SDF and SDS, respectively. The adsorbents under consideration follow pseudo-second order kinetics. Thermodynamic parameters depict that the $\mathrm{Cu}$ (II) biosorption is feasible, endothermic and occurs with increased randomness for SDS biosorbent while the biosorption using SDF and SDB is exothermic and takes place with a decrease in randomness between solid-liquid interfaces. Desorption studies showed that acidic desorbing agents like $\mathrm{HCl}, \mathrm{HNO}_{3}$ and $\mathrm{H}_{2} \mathrm{SO}_{4}$ have higher desorption efficiency in comparison to $\mathrm{NaOH}$ and KI. The results of percentage adsorption of processed adsorbents signify them to be efficient and sustainable adsorbents for the uptake of cupric ions. The method used for the removal of $\mathrm{Cu}$ (II) ions may get wider acceptability due to its ease in execution at the industrial level. The abundant availability, cost-effectiveness and efficiency of the adsorbents further add to their wider acceptability. The adsorbents under study meet the above-mentioned expectations paving a clear path towards its future utility. Authors do not object to rating these adsorbents as competent biosorbents. The adsorbents have great unexplored potential, so, in further studies, the adsorption capability of sawdust can be modified by converting it into nanocomposites.

\section{ACKNOWLEDGMENT}

IKGPTU, Kapurthala is highly acknowledged by authors for extending research opportunity. Authors are thankful to GZSCCET, Bathinda for providing a laboratory to carry out experimental work. Additionally, the first author is indebted to UGC, New Delhi for awarding teacher fellowship and PU, Patiala (parent organization) for allowing study leave to accomplish the research.

\section{REFERENCES}

1. M. Ghasemi, M. Naushad, N. Ghasemi, and Y. Khosravi-fard, J. Ind. Eng. Chem., 20(2), 454(2014), DOI:10.1016/j.jiec.2013.05.002

2. V.H. Waghmare and U.E. Chaudhari, Rasayan J. Chem.,7(4), 375(2014)

3. A. Ahmad, M. Rafatullah, O. Sulaiman, M.H. Ibrahim, Y.Y. Chii, and B.M. Siddique, Desalination., 247(1), 636(2009), DOI:10.1016/j.desal.2009.01.007

4. H. Muhamad, H. Doan, and A. Lohi, Chem. Eng. J., 158(3), 369(2010), DOI:10.1016/j.cej.2009.12.042

5. B. Singha and S.K. Das, Colloids Surfaces B Biointerfaces., 107, 97(2013), DOI: 10.1016/j.colsurfb.2013.01.060

6. F. Ekmekyapar, A. Aslan, Y.K. Bayhan, and A. Cakici, J. Hazard. Mater., 137(1), 293(2006), DOI: 10.1016/j.jhazmat.2006.02.003

7. N. Neyaz and W.A. Siddiqui, Int. J. Sci. Res.,4(2), 1868 (2015)

8. Z.-Y. Yao, J.-H. Qi, and L.-H. Wang, J. Hazard. Mater., 174, 137(2010), 
RASĀYAN J. Chem.

Vol. 12 | No. 3 |1247 - 1261| July - September | 2019

DOI: $10.1016 /$ j.jhazmat.2009.09.027

9. E. Pehlivan, T. Altun, and Ş. Parlayici, Food Chem., 135(4), 2229(2012), DOI: 10.1016/j.foodchem.2012.07.017

10. M.E. Argun, S. Dursun, C. Ozdemir, and M. Karatas, J. Hazard. Mater., 141(1), 77(2007), DOI: 10.1016/j.jhazmat.2006.06.095

11. K.T. Dauda, V.N. Atasie, and O. Adeoye, Int. J. Adv. Res. Chem. Sci., 2(4), 13(2015)

12. M. Gorgievski, D. Božić, V. Stanković, N. Štrbac, and S. Šerbula, Ecol. Eng., 58, 113(2013), DOI: $10.1016 /$ j.ecoleng.2013.06.025

13. M.A. Hossain, H.H. Ngo, W.S. Guo, and T.V. Nguyen, Bioresour. Technol., 113, 97(2012), DOI: $10.1016 /$ j.biortech.2011.11.111

14. F.C. Khorasgani, Int. J. Environ. Eng. Manag., 4(4), 273(2013)

15. V.C. Taty-Costodes, H. Fauduet, C. Porte, and Y.-S. Ho, J. Hazard. Mater., 123(1-3), 135(2005), DOI: 10.1016/j.jhazmat.2005.03.032

16. Y. Liu, Q. Cao, F. Luo, and J. Chen, J. Hazard. Mater., 163(2), 931(2009), DOI: 10.1016/j.jhazmat.2008.07.046

17. F.N. Acar and Z. Eren, J. Hazard. Mater., 137(2), $909 \quad$ (2006), DOI: $10.1016 /$ j.jhazmat.2006.03.014

18. H.J. Rao, P. King, and Y.P. Kumar, Rasayan J. Chem., 11(3), 1376(2018), DOI: 10.31788/RJC.2018.1134035

19. S.S. Baral, S.N. Das, and P. Rath, Biochem. Eng. J., 31(3), 216(2006), DOI: $10.1016 /$ j.bej.2006.08.003

20. M. Bansal, U. Garg, D. Singh, and V.K. Garg, J. Hazard. Mater., 162(1), 312(2009), DOI: 10.1016/j.jhazmat.2008.05.037

21. M. Bansal, A Mudhoo, V.K. Garg, and D Singh, Int. J. Environ. Sci. Technol., 11(5), 1399(2014), DOI: $10.1007 / \mathrm{s} 13762-013-0293-1$

22. N. Kataria and V.K. Garg, Chemosphere., 208, 818(2018), DOI: $10.1016 /$ j.chemosphere.2018.06.022

23. M. Basu, A.K. Guha, and L. Ray, J. Environ. Chem. Eng., 3(2), 1088(2015), DOI: $10.1016 /$ j.jece.2015.04.024

24. D.H.K. Reddy, K. Seshaiah, A.V.R. Reddy, M.M. Rao, and M.C. Wang, J. Hazard. $\quad$ Mater., 174(1), 831(2010), DOI: 10.1016/j.jhazmat.2009.09.128

25. M. Zabihi, A. Haghighi Asl, and A. Ahmadpour, J. Hazard. Mater., 174(1), 251(2010), DOI: $10.1016 /$ j.jhazmat.2009.09.044

26. I. Langmuir, J. Am. Chem. Soc., 40(9), 1361(1918), DOI: 10.1021/ja02242a004

27. H.M.F. Freundlich, J. Phys. Chem., 57, 385 (1906).

28. N. Kataria, V.K. Garg, M. Jain, and K. Kadirvelu, Adv. Powder Technol., 27(4), 1180(2016), DOI: $10.1016 /$ j.apt.2016.04.001

29. M.M. Dubinin and L.V. Radushkevich, Chem. Zentr., 1, 875(1947)

30. P.S. Kumar, S. Ramalingam, S.D. Kirupha, A. Murugesan, T. Vidhyadevi, and S. Sivanesan, Chem. Eng. J., 167(1), 122(2011), DOI: 10.1016/j.cej.2010.12.010

31. M.I. Temkin and V. Pyzhev, Acta Phy. Chem, USSR., 12, 327(1940)

32. S. Lagergren, K. Sven. Vetenskapsakademiens Handl., 24, 1(1898)

33. Y.S. Ho and G. McKay, Process Biochem., 34(5), 451(1999),DOI: 10.1016/S00329592(98)00112-5

34. W.J. Weber and J.C. Morris, J. Saint. Eng. Div. Am. Soc. Civ. Eng., 89, 31(1963)

35. H. Teng and C.T. Hsieh, Ind. Eng. Chem. Res., 38(1), 292(1999), DOI: 10.1021/ie980107j

36. M.H. Kalavathy and L.R. Miranda, Desalination., 255(1), 165(2010), DOI: $10.1016 /$ j.desal.2009.12.028

[RJC-5171/2019] 